Bangladesh Journal of Anatomy January 2010, Vol. 8 No. 1 pp. 21-27

\title{
Prediction of Stature From Hand Length and Breadth - An Anthropometric Study on Christian Garo tribal Bangladeshi females
}

\author{
Samira Hossain ${ }^{1}$, Jahan Ara Begum², Mst. Laila Anjuman Banu³ ${ }^{3}$ Md. Fashiur Rahman ${ }^{4}$, Zakia Akhter ${ }^{5}$
}

\begin{abstract}
:
Context: Body physique is influenced to a greater extent by climatic, hereditary, nutritional and racial factors. Since in Bangladesh variegated ethnic groups inhabit in different conditions, no single anthropometric formula is suitable. The stature prediction occupies relatively a central position in the anthropometric research. And estimation of stature of an individual from the mutilated or amputated limbs has obvious significance in the personal identification in the events of murders, accidents or natural disasters. The present study was undertaken to measure the stature, as well as some length and breadth of hand and to determine whether there is any correlation between the stature and the hand variables. And to estimate using respective multiplication factors the stature from these variables and to assess the effectiveness of the above estimations by comparing the 'estimated' values with the 'measured' values.

Methods: The study was carried out with a total number of 100 Christian Garo adult females aged between 25 to 45 years. Hand length and breadth along with their stature were measured directly from the subjects by using anthropometric sliding, spreading calipers and measuring tape. The data were then statistically analyzed by computation to find out its normative value. Multiplication factors were estimated for estimating stature and comparison were made between measured and estimated stature using paired " $t$ " test.
\end{abstract}

Result: The mean normal values of the hand measurements (right and left hand length were $16.39 \pm 0.72 \mathrm{~cm}$ and $16.33 \pm 0.67 \mathrm{~cm}$ respectively and breadth of right and left hand were $7.22 \pm 0.38 \mathrm{~cm}$ and $7.18 \pm 0.3 \mathrm{~cm}$ respectively) and the stature $(152.79 \pm 5.62 \mathrm{~cm})$ were found. The multiplication factors were estimated for the same hand measurements with the stature. Significant positive correlation was found in case of hand length with the stature. There was positive correlation $(r=0.17, p=0.09$ and $r=0.15, p=0.12)$ between the stature and breadth of the right and left hand (Figure 3.21) but the result did not reach any statistically significant level.

Key words: Anthropology, correlation, multiplication factor, stature

\section{Introduction}

There is a long record of discussion on the issue of human variation in anthropometric research. Anthropologists observe and compare the relationship between body segments to highlight

1. Assistant Professor, Department of Anatomy, Green life Medical College, Dhaka

2. Professor, Department of Anatomy, BSMMU, Dhaka

3. Associate professor, Department of Anatomy, BSMMU, Dhaka

4 Medical Officer, Dermatology and Venereology, Dhaka Medical College Hospital, Dhaka

5 Assistant professor, Department of Anatomy. Z.H. Sikder Women's Medical College, Dhaka

Correspondence: Dr. Samira Hossain variations between ethnic origins ${ }^{1}$.Yet, when health risk is defined in terms of body size, Western Caucasian standards have, by default, become the international standard. Although by far the most longterm data available on health risks are from Caucasian subjects, there is mounting evidence that these Western standards may not be applicable to $\mathrm{all}^{2}$. They may, for instance, be too generous for people of Asian origin or too stringent for Polynesian adults. It is therefore agreed that different formulae will be required for calculating stature from different segments in different populations. The indigenous hill tribe is one of the main attractions in Bangladesh .These tribal people differ noticeably from the rest of the population of Bangladesh in terms of their 
appearance, language, religion and social organization. The tribes tend to intermingle and could be distinguished from one another more by differences in their dialect, dress, and customs ${ }^{3}$.

\section{The People:}

The Garo (Mendi) Adivasi, a distinguished matriarchal community of Bangladesh living in the north-eastern parts of the country especially in Gazipur, Mymensingh, Netrokona, Tangail, Sherpur, Jamalpur and some in Sylhet districts close to the Indian border 4 . According to the Census report in $1991^{5}$, there are 64,280 Garos who live in Bangladesh. Almost all the Garo are bi-lingual because they have to speak Bengali in addition to their Garo language. Garos have their own language, which is called 'Achchik Katha'. The traditional Garo religion is 'Sangsharek', which is almost abolished .Over the years, most of the Garo have been converted to Christianity and a few into Islam ${ }^{6}$. The mass populations of the villages are literate. With the introduction of formal schooling, Garo took the opportunity to be educated which has influenced and changed Garo in their lifestyle.

\section{Methods:}

The study was basically observational, crosssectional and descriptive in nature. The study was carried out on 100 Christian Garo adult females at different locations of Dhaka city and Mymensingh district. To measure the stature the subject was said to stand with her heel together and her back as straight as possible so that her heels, buttocks, shoulders and the head touched the wall. The arms were hung freely by the sides with the palm facing the thighs ${ }^{7}$. After asking the subject to take a deep breath and holding it, a measuring scale (steel plate) was placed against the head and wall to determine maximum height on the wall, and this was marked .The subject was then told to breathe and to step away from the wall. The height was then measured from the floor to the mark on the wall with steel tape which represents the stature in centimeters to the nearest 0.1 centimetres $^{8}$. The length of hand was measured as the straight distance from the distal wrist crease to the most forwardly projecting point on the middle finger. A manual sliding caliper was used to measure the hand length (Figure 1). Breadth of the hand was measured as the width of the hand from the lateral surface of metacarpal II to the medial surface of metacarpal $\mathrm{V}$ (Figure 2). The hand was placed on a table with the fingers together and the thumb out to the side with a sliding caliper the breadth of the hand was measured at the level of the knuckles ${ }^{9}$.

\section{Calculations of multiplication factor:}

Each multiplication factor is the ratio of the stature to the respective physical measurements. A mean multiplication factor was then calculated for each measurement. These mean multiplication factor were used for estimating the stature from those variables.

According to Lal and Lala ${ }^{10}$ multiplication factor is

M .F $=\frac{\text { Stature }}{\text { Hand variables (e.g. length) }}$

\section{Statistical analyses of data}

Results were prepared on the basis of collected data and their distributions, central tendencies and standard deviations (SD) were calculated using a computer based programme (SPSS version-11.5 \& MS Excel). Regression analysis were done .Mathematical relationships between sets of two measurements were calculated as multiplication factors (i.e., ratios between the two).Using the paired $t$ test, the measured values were compared with the corresponding values estimated (using the corresponding multiplication factors) from other relevant measurements.

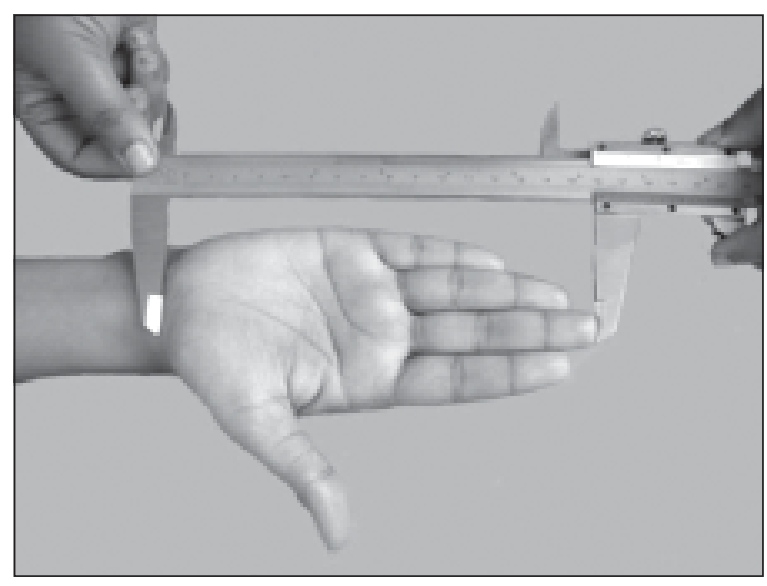

Fig: 1 : Procedure for measuring the length of hand by using manual sliding caliper. 


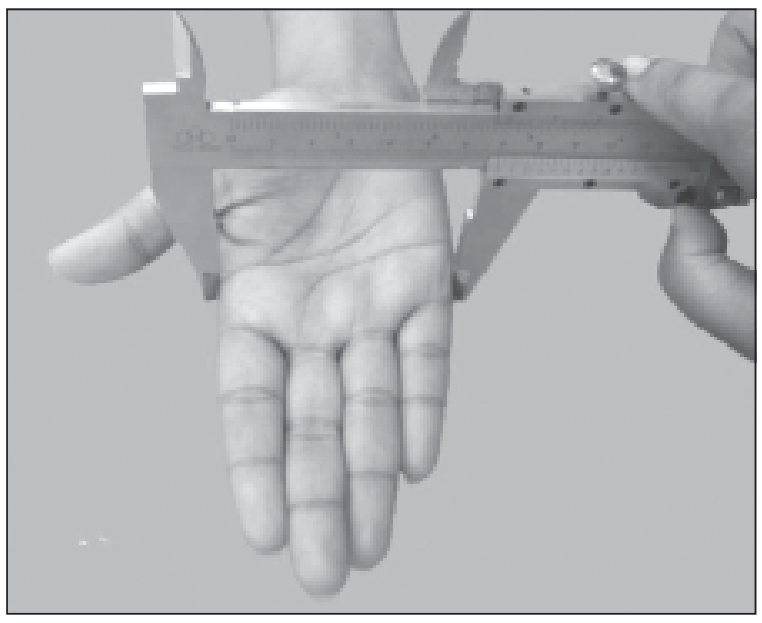

Fig.-2: Procedure for measuring the breadth of hand using manual slide caliper.

\section{Results:}

The mean values of the stature, hand length and hand breadth were found. The mean ( \pm SD) of the stature was found $152.79 \pm 5.62 \mathrm{~cm}$ (Table 1 ). The length of the right hand of subjects varied from 14.70 to 17.94 centimeters, as shown in Table 1 . In more than $80 \%$ of the subjects, the length of the right hand was between 15.00 and 16.99 centimetres
(Figure 3). The length of the left hand of these subjects varied from 14.80 to 18.23 centimeters, as shown in Table 1 . In more than $80 \%$ of the subjects, length of the left hand was between 15.00 and 16.99 centimetres (Figure 4). The length of the right and left hand showed significant positive correlation $(r=0.51, p=0.000$ and $r=0.49, p=0.000)$ with the stature (Figure 7 and 8 ).

The breadth of the right hand of these subjects varied from 6.31 to 8.06 centimeters, as shown in Table 1. In more than $70 \%$ of the subjects, the breadth of the right hand was between 6.50 and 7.49 centimetres (Figure 5). The breadth of the left hand of these subjects varied from 6.26 to 8.04 centimeters, as shown in Table 1. In more than 70\% of the subjects, breadth of the left hand was between 6.50 and 7.49 centimetres (Figure 6) There was positive correlation $(r=0.17, p=0.09$ and $r=0.15$, $\mathrm{p}=0.12$ ) between the stature and breadth of the right and left hand (Figure 9 and 10) but the result did not reach any statistically significant level.

The multiplication factor (M.F.) regarding the breadth of right and left hand for estimating stature is mentioned in Table 1

Table-I

Stature and different, their descriptive statistics, multiplication factors and correlation with stature

\begin{tabular}{lcccc}
\hline Variable & $\begin{array}{c}\text { Range } \\
(\mathrm{cm})\end{array}$ & $\begin{array}{c}\text { Mean }(\mathrm{cm}) \\
\pm \mathrm{SD}\end{array}$ & $\begin{array}{c}\text { Mean } \\
\text { multiplication } \\
\text { factor }\end{array}$ & $\begin{array}{c}\text { Significance of } \\
\text { correlation } \\
\text { (p value })\end{array}$ \\
\hline $\begin{array}{l}\text { Stature } \\
\text { Length of hand } \\
\quad \text { Right }\end{array}$ & $137.00-168.50$ & $152.79 \pm 5.62$ & & $0.00(\mathrm{~S})$ \\
$\quad$ Left & $14.70-17.94$ & $16.39 \pm 0.72$ & 9.33 & $0.00(\mathrm{~S})$ \\
$\quad \begin{array}{c}\text { Breadth of hand } \\
\quad \text { Right }\end{array}$ & $14.80-18.23$ & $16.33 \pm 0.67$ & 9.37 & $0.00(\mathrm{~S})$ \\
$\quad$ Left & & & & \\
\hline
\end{tabular}

$\mathrm{n}: 100$ for each variable

S: significant at $5 \%$ level in regression analysis

NS: Non significant

In this study, each hand variables was multiplied by mean multiplication factor and then estimated stature was obtained and then calculating the mean for 100 estimated values. This is shown in Table 2 
Table-II

Comparison between the 'measured' stature and the stature 'estimated' from hand length and breadth

\begin{tabular}{|c|c|c|c|c|}
\hline \multirow{2}{*}{$\begin{array}{l}\text { Measurement from which } \\
\text { the stature was estimated }\end{array}$} & \multirow{2}{*}{$\begin{array}{c}\text { Measured } \\
\text { stature }(\mathrm{cm}) \\
\text { Mean } \pm \text { SD }\end{array}$} & \multicolumn{2}{|c|}{ Estimated Stature $(\mathrm{cm}) \dagger$} & \multirow{2}{*}{$\begin{array}{c}\text { Significance of } \\
\text { difference } \\
\text { (p value) }\end{array}$} \\
\hline & & Range & Mean \pm SD & \\
\hline \multicolumn{5}{|l|}{ Length of hand } \\
\hline Right & & 137.15-167.38 & $152.96 \pm 6.70$ & $0.88(N S)$ \\
\hline \multirow[t]{2}{*}{ Left } & & 138.68-170.82 & $153.05 \pm 6.31$ & 0.75(NS) \\
\hline & $152.79 \pm 5.62$ & & & \\
\hline \multicolumn{5}{|l|}{ Breadth of hand } \\
\hline Right & & 133.90-171.03 & 153.21土8.03 & 0.70(NS) \\
\hline Left & & 133.65-171.65 & $153.23 \pm 8.00$ & 0.68(NS) \\
\hline
\end{tabular}

†The mean estimated stature against each hand variable was obtained by multiplying each individual value for that variable by the respective mean multiplication factor (as shown in table 3.1) and then calculating the mean for that.

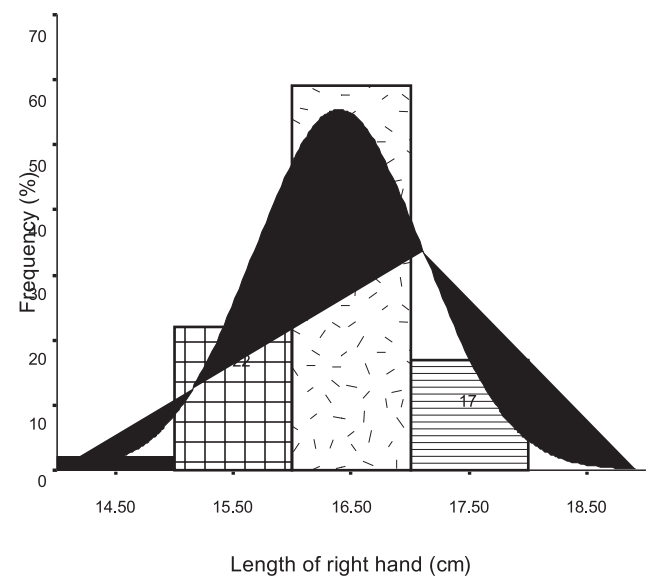

Fig.-3: Frequency curve showing the frequency distribution of the length of the right hand.

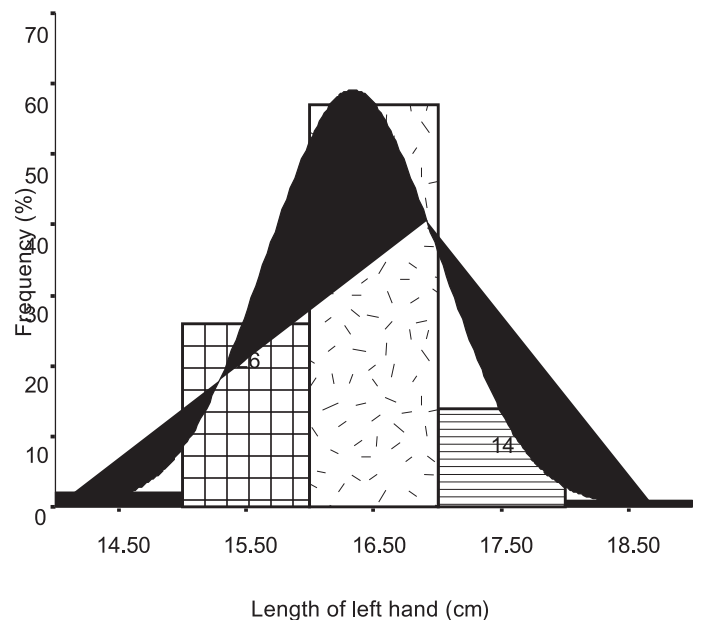

Fig.-4: Frequency curve showing the frequency distribution of the length of the left hand

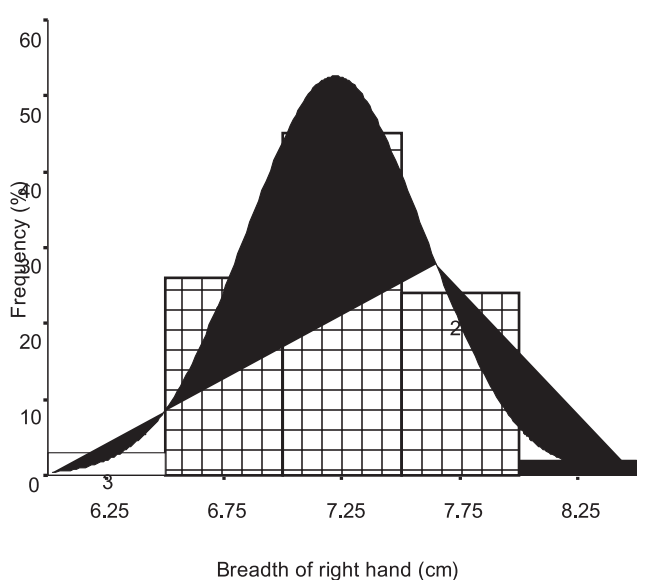

Fig.-5: Frequency curve showing the frequency distribution of the breadth of the right hand.

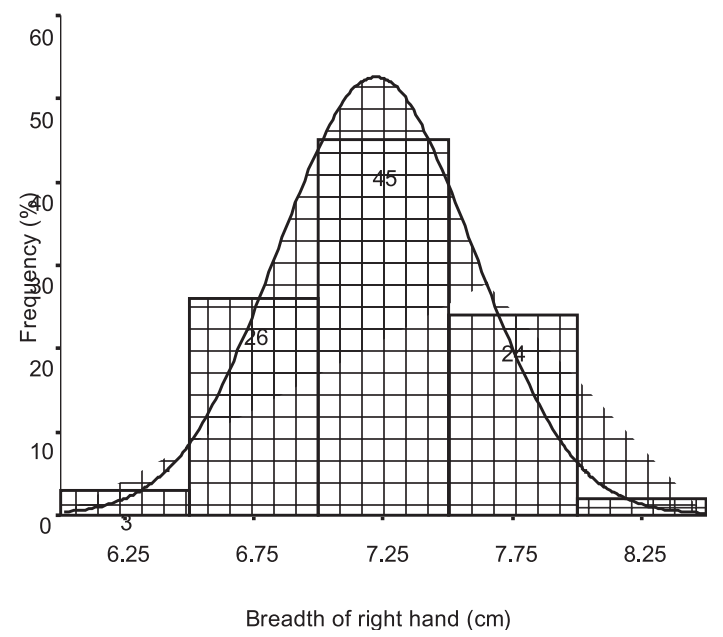

Fig.-6: Frequency curve showing the frequency distribution of the breadth of the left hand 


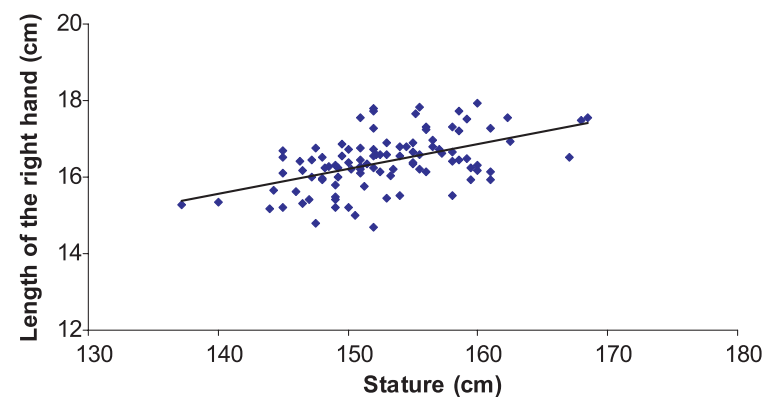

Fig.-7: Scatter diagram with regression analysis showing positive correlation $(r=0.51)$ between the stature and length of the right hand

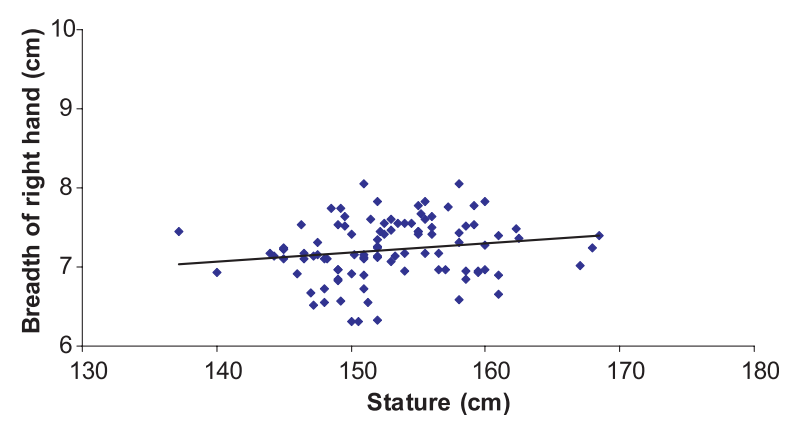

Fig.-9: Scatter diagram with regression analysis showing positive correlation $(r=0.17)$ between the stature and breadth of right hand

\section{Discussion:}

Although no statistical analysis could be done between the results of the present study and those of other studies, some observations may be worth mentioning. As the Garo tribe belongs to the Mongoloid race, some similarities are expected to exist with the other ethnic groups of Mongoloid race and some dissimilarity may be expected with other races. In the present study, the mean stature of the Garo females was found as $152.79( \pm 5.62)$ centimetres. The mean stature of the Japanese and Chinese ${ }^{11}$ females has been found somewhat closer to this value. The urban Bengali females ${ }^{12}$ and the females of some Indian ethnic groups like South Indians ${ }^{13}$ appears to show a higher mean stature than the Garo females. However, rural Bengali females ${ }^{14}$ and Indians like Santhals of West Bengal ${ }^{15}$ had lower value than the Garo female population. Higher mean stature was also be noted in the Caucasian females of Mexican 16

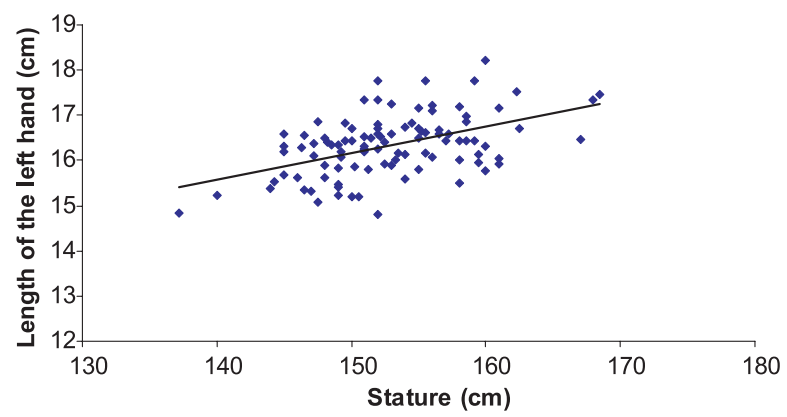

Fig.-8: Scatter diagram with regression analysis showing positive correlation $(r=0.49)$ between the stature and length of the left hand

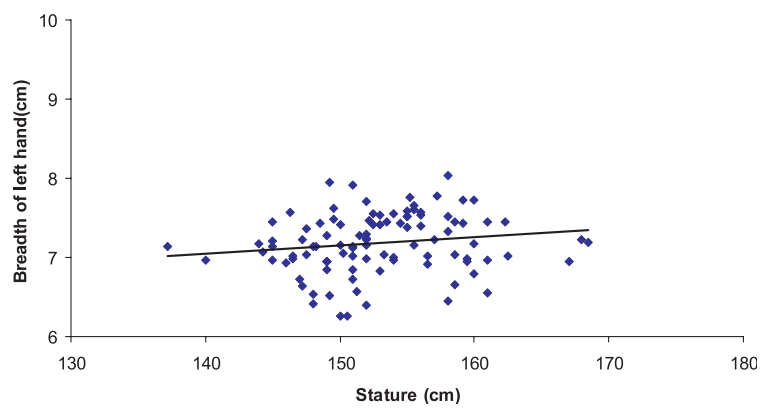

Fig.-10: Scatter diagram with regression analysis showing positive correlation $(r=0.19)$ between the stature and breadth of the left hand.

origin. It should be noted that the highest mean stature was found in the Negroid adult females like the Somali in Ethiopia ${ }^{1}$.The mean length of right hand was 16.39 and left hand was 16.33 centimetres and the average value was 16.36 centimetres in the present study. Similar value was reported in Bengali adult females ${ }^{12}$. Higher value was also found in Punjabi females ${ }^{17}$, Mangalore females and other Indian females ${ }^{18}$, while Nigerian females ${ }^{20}$ belong to Negroid race, showed higher value.In the present study, the mean breadth of right hand was 7.22 and left hand was 7.18 centimetres. Average value was 7.20 centimetres. Smaller value was reported in Bengali adult females ${ }^{12}$ and in Indian females ${ }^{18}$. Higher value was only found in Nigerian females ${ }^{19}$ of Negroid race and in Turks ${ }^{20}$ females of Caucasoid race. From the above view it may be suggested that variation is not only present in between races or ethnic groups but also present among individual races or ethnic groups. While in question of correlation of stature and between hand length and 
breadth, it was found that hand lengths have significant positive correlation with stature. On the other hand, hand breadth found to have non significant correlation with stature.

\section{Conclusion:}

Though the sample size was small and the convenience sampling had to be applied due to time constrains as well as because the study was done on such a group of people where a sampling frame could not be constructed, results of the present study will provide a baseline information, regarding some variables of a particular population (defined for the present study as Christian adult Garo females. It could lead to the development of a standard for such data on various subgroups of the population (and the population as a whole).Some amount of comparisons made with other population could contribute to the understanding of the relative status of our Garo population in the context of the anthropometric variations around the world. Significant correlations, as detected in the study between some of the measurements and their implications in the development of proper multiplication factors to be useful in estimating one measurement from another. This should encourage others in taking up further research in the field. The similar study might be done on the tribals like Chakma, Marma, Santhals, Tipra, Murong and others, while relationship of stature with other parameters (lower limb dimensions etc) of the body could also be considered.

\section{References}

1. Lucia E, Leema F, Tesfaye F, Demisse F, Ismail S, 2002. The use of arm span measurement to assess the multinational status of adults in four Ethiopian ethnic groups. European Journal of Clinical Nutrition 2002 [Online], 56.

2. Craig P, Halavatau V, Comin E, Caterson I. Differences in body composition between Tongans and Australians: time to rethink the healthy weight ranges? International Journal of Obesity 2001; [Online], 25.
3. Country overview [Online]. Available from: $h$ ttp:/ /www.nationsencyclopedia.com [Accessed $16^{\text {th June 2008]. }}$

4. Banglapedia Garo, the [online]. Available from: http://banglapedia.search.com.bd_[Accessed 23rd June 2008].

5. Islam R, 2008. The changing Garo Adivasi Culture of Bangladesh: A case study of marriage Ritual. Thesis (M Phil). University of Tromso, Norway.

6. Ellen B.. They ask if we eat frogs: social boundaries, ethnic categorization and the Garo people of Bangladesh 1999; [Online]. Netherlands, Uitgeverij Eburon Press limited.

7. Brown KJ, Feng Z, Knapp RT. Is Self-Reported Height or Arm Span a More Accurate Alternative Measure of Height? Clinical nursing research 2002, [Online], 11 .417-432

8. Frisancho AR. Anthropometric standards for the assessment of growth and nutritional status [Online]. USA, The University of Michigan Press. 1990.

9. Humosim Anthropometric measurements [Online]. Available from: Center For Ergonomics.University of Michigan.1205 Beal Avenue. Ann Arbor, Michigan 48109-2117(734) 763-0570

10. Lal CS, Lala JK, 1970. Estimation of height from tibial and ulnar length in North Bihar. Journal of Indian Medical Association [Online], 58(4). Available from: http//www.ncbi.nlm. nih.gov/pubmed/5021709 ${\text { [Accessed } 28^{\text {th }}}$ November 2008].

11. Human Height [Online]. Available from: http:// www. answers. com/topic/ height [Accessed $18^{\text {th }}$ August 2007]

12. Laila SZH, 2008. Anthropometric measurements of the upper limb and their relationships with the stature and the hand shape, frame size and somato type of Bangali adult Muslim females. Thesis (M.Phil). BSMMU, Bangladesh. 
13. Mohanty SP, Babu SS, Nair NS. The use of arm span as a predictor of height: A study of South Indian women. Journal of Orthopaedic Surgery [Online], 2001; 9(1). 9].

14. Hosegood V, CampbellO, MR. Body mass index, height, weiuman height, arm circumference and mortality in Bangladeshi women: a 19y longitudinal study. American Journal of Clinical Nutrition 2003; [Online], 77 ..

15. Ghosh S, Malik SL. Sex Differences in body size and shape among Santhals of West Bengal. Anthropologist 2007, [Online], 9(2).

16. Lavender SA, Marras WS, Sabol RJ. AStudy of Female Mexican Anthropometric Measures Useful for Workstation Design in Light Manufacturing Facilities. AlHA Journal 2002; [Online], 63].
17. Jasuja OP, Singh J, Main M. Estimation of stature from hand and phalangeal length. Journal of Indian association of forensic Medicine [Online], 2004; 26(3).

18. Nag PK, Desai H, Nag A. Hand anthropometry of Indian women. Indian J Med Res 2003; [Online],117.

19. Danborno B, Elukpo A. Sexual dimorphism in hand and foot length, indices, stature-ratio and relationship to height in Nigerians. The Internet Journal of Forensic Science 2008; [Online], 3(1).

20. Sanli SG, Kizilkanat ED, Boyan N, Ozsahin ET, Bozkir MG, Soames R et al, 2005. Stature Estimation Based on Hand Length and Foot Length. Clinical Anatomy 2005; [Online], 18. 